\title{
UNDERSTANDING ADOPTION FACTORS OF SUBSCRIPTION BASED ENTERTAINMENT SERVICES AMONG CONSUMERS IN INDIA
}

\author{
Tanya Khatri ${ }^{1}$ \\ ${ }^{1}$ Symbiosis Institute of Business Management, Electronics City, Hosur Road, Bengaluru, Karnataka
}

\begin{abstract}
The market of subscription-based entertainment services in India has grown in the last few years, due to the changing lifestyle, preferences and the deluge of choices that are there for the customers. There has been a substantial increase in Customer acquisition especially in paid streaming video, music and gaming subscriptions. People are adding new services to have access to new and diversified content which is more personalized and offer them a more enriching experience. The market for subscription model-based entertainment services in India has seen growing trends and offers an opportunity to understand the consumer preferences better. $A$ trend in Indian customers has shown the preference of streaming services over buying or downloading it. The objective of this paper is to identify the factors influencing the subscribing intention of the entertainment services in India. In this paper, quantitative descriptive crosssectional research design has been used, a hundred and fifty-four people were chosen through a systematic random sampling technique from different demographics. The people were categorised into different age groups such as Gen-Z (14-23 years), Millennials (24-37 years) and Gen-X (38-54 years) and then their preferences were studied based on their answers in survey questionnaire. Along with age there were other demographic factors that were taken into consideration to draw the conclusions. In general, descriptive results show that the interviewed consumers have subscribed to these channels and the consumer base for these services is here to stay.
\end{abstract}

Keyword: Kruskal Wallis test, Mann-Whitney U test, Subscription services, Streaming services, perception, Over the top platform, purchase Intention, Automation, Music Streaming, Media, online Entertainment.

\section{Introduction}

The industry of Over-the top platforms is growing in India, which is a new found side of the recent shifts in the entertainment demand in the whole country [14]. The rapidly rising subscription models in these services has given industry experts an opportunity to compare several attributes of traditional model of media Industry and the newly followed pathways. Due to change in lifestyles, consumers' demand and preferences of these services imply on the deciding the new engaging activities over these platforms. However, the awareness of the customer attitude towards these services is not clear in India.

In India, the demand of subscription-based services is becoming more and more critical as the direction of strategies for entertainment Industry are influenced by the consumer attitudes and preferences. This shift in market is due to consumers' interest for variety of content, ease of access and content personalization [18]. Hence, there has been a belief that these subscription-based models are what is attracts more and more people giving them the power.

With the advent of these platforms, there has been a deluge in platforms, both in video streaming services and music Industry. An overall development in Media Industry can be seen, where even print media has undergone a digital transformation and is now trying to reach its customer more [24]. There are transformations done by different sectors in media industry where they have adopted measure to have a direct contact with their customers and provide them with a personalized experience. From consumption of videos to listening music and now reading newspapers, the customer base surely has a changed set of preferences. Currently, perception of these subscription-based services is utilitarian as there are many offers and services being bundled along with the core service that drive the customer base to the concerned service.

Currently, there is little known about Indian consumers' concerns and attitudes towards the subscription-based models in general. These models are now going beyond the entertainment industry and are becoming the strategies of many diversified businesses.

Understanding consumer's preference for subscription model of services in Entertainment Industry in India is extremely critical for the sustainability of these models and also influences the direction of the owners of these services. The paper tries to understand the attributes that are most important for the people to go for these subscription services while looking for entertainment. The paper covers the video streaming services, music streaming services and subscription to online newspapers.

\section{REVIEW OF LITERATURE}

Moochhala, Q. (2018) in their study discovered the scope of the streaming industry. It focuses on factors that has led to the deluge of these services in India. The study talks about how 
penet

ration of smart phones is one of the contributing factors in people switching on to these services. India's digital revolution can be attributed to more access that people now have to internet, as much as one-third of India's population now has access to the internet services in the country. The study also talks about OTT and its effects on the traditional media platforms and what is making people switch to these services. The demographic factors have been taken into consideration for the study. However, the attributes that play a role in taking a decision while subscribing to one of these services were not covered in the paper and this is the gap that can be looked at in the study.

Sivamol, S., \& Suresh, K. (2019). In their study covered the 'human' factor along with system design in understanding issues to adopting technology. This study was done in order to understand the user-perspective and their computational approach towards recommendation services. It studies the effects of recommendations and their personal characteristics in order to advance a full consideration of the user experience. While the given paper does focus on the personal characteristics and recommendations, the other attributes while targeting the customer base in this segment are not considered. In order to understand the customer base properly certain more aspects based on various psychological theories to be considered and thus a gap that can be worked upon.

Sundaravel, E., \& Elangovan, in their study talk about various OTT services, what are the factors that affect their growth, what kind of technical background do these players have, what sort of audience characteristics they seek and the future developments expected in the Industry. They talk about the paradigm shift that the traditional cable $\mathrm{Tv}$ will have to go through. They have taken into consideration the marketers who can now align themselves according to the viewer preference towards digital media. A better lay out or strategy for the marketers can be studied and thus be presented to them in order to position their service better.

Chatterjee, M., \& Pal, S. (2020) in their study talk about how the advent of digital media has changed the scope for cinema in India. They talk about changing media consumption patterns and the reasons behind it. They try to find why people are switching to mobile devices rather than sticking to big cinema screens. Apart from price considerations the user experience is taken into account and how people feel about the same. With this in line they draw conclusions on the future of Indian cinema. Their study showed that consumers prefer OTT content due to not only because of the technical evolution but the socio-economic factors and behavioural changes also play a major role. A deeper insight on these factors will be useful for the marketing of these services in future.

Dasgupta, D., \& Grover, D. (2019) have targeted mainly millennials in their study and have carried out research on their behaviour only. They talk about consumption patterns and adoptability factors of OTT among millennial consumers.

\section{Factors like}

convenience, mobility, content and subscription services were studied in the youth for their switch from traditional media to the digital platforms. The paper in its future scope mentions that it takes into consideration consumer's point of view in terms of the consumption of the video and not taking in to consideration picture of other platforms, thus these can be targeted in the study conducted.

Selvakumar, E., Huang, J., Aidi, L., Markendahl, J. I., Tollmar, K., \& Blennerud, G. talk about music streaming services in India, Indonesia and China. They explore the value that can be catch up in the new business opportunity. They look at the potential drivers and obstacles of mobile streaming service business in India, China and Indonesia. Although they did conduct a study with respect to the businesses, aspects related to customers and driving them to subscribing these services were not covered and hence can be part of the study.

\section{MATERIALS AND METHODS}

\subsection{Research design}

For this paper quantitative research approach has been adopted. This type of research gave a flexibility in handling the data and also perform statistical analysis, do comparative studies and restate the collected data which confirms the reliance of the instruments used. The research design was cross-sectional and the data was collected using survey method which is comparatively easier, cheap and is an efficient to conduct also allowing to adequately capture the variables of interest and information of interest.

3.1.1 Conceptual Framework of the attributes that influence the Consumer's decision to go for subscription-based models in Media and Entertainment Industry

An attribute of human behaviour generally influences the intention to make decision. The consumers' behaviour can be described by the collection of actions that are intended to meet the need of individuals with different traits. Over the years, many theories have been conceptualized for consumer behaviour which include for example; cognitive approach, rising income theory, the economic man approach, behaviouristic approach and the psychodynamic approach. The actions or traits that constitutes the human personality concerning consumer behaviour are considered under the cognitive approach. A human's environment in which he or she lives impacts the process of internal decision-making by the consumer [5]. The cognitive theory hence describes the purchasing decision as problem-solving in nature. According to rising income theory, the spending of the consumer increases as per the increase in the income, this fact is contradicted by the behaviouristic approach which states that this increase in earning does not follow the same trend for all the consumers.

Behaviour can be explained as the set of actions that a person exhibits when it comes into contact with the external environment $[6,7]$. 
The

economic man approach states that a consumer has the capability of ranking the available choices according to their worth whilst making the best decisions for themselves [8]. This approach doesn't hold true for every product as some products are bought by the consumers without putting much thought into them, also known as low-involvement product. The psychodynamic approach states that biological influences via internal drives influences the thought process of the consumer [9].
According to

Consumer behaviour theory, various attributes influencing the consumer purchase decisions to go for subscription-based model could be due to demographics of consumer (age, gender, Income, employment status) which can further influence the consumer knowledge to purchase the subscription for various entertainment services.

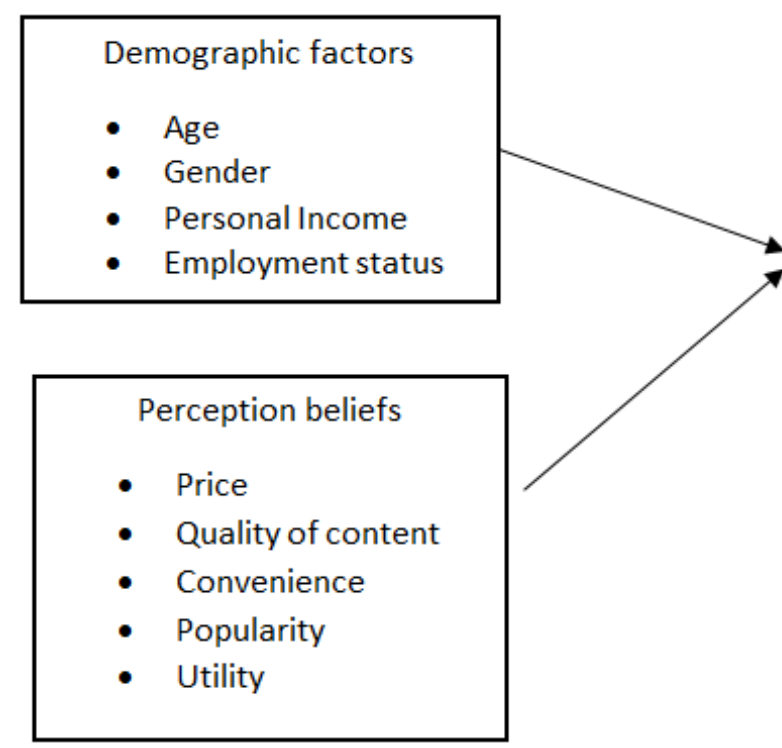

3.1.2 Study population, Sample size and Procedure

The target populations were the consumers of subscriptionbased entertainment services in India. According to Du Plooy [1], to gather precise data about a group it is important to deal with an adequate sample size. It is evident that larger sample size is more reliable than smaller samples which may lead to decrease in the level of accuracy but is moderately accessible and cheap [2]. The sample size of this paper is of 154 respondents. Plausibly, the size of sample is not large enough and might reduce the level of accuracy and reliability of the collected data. Nevertheless, this sample size is deemed to be adequate to perform statistical analysis while being small enough to manage. To collect the sample, a systematic random sampling procedure was employed and a survey form was floated in order to collect the responses.

\subsection{Data collection}

A pre-tested structured questionnaire was used to collect the data. This pre-testing of the questionnaire helped in enhancing the validity and reliability of the questionnaire which will further enhance the quality if the data collected. The structured questionnaire was used to collect information from the consumers for example, their demographics, their preferences, their choices with respect to these services. Their opinion on this subscription-based economy were collected so as to further help the companies to incorporate this business model as their long-term business strategy. The factors that were basically addressed in the questionnaire were based on the services that consumers get when they subscribe to such media services. It ranged from the importance of content, regional language to content for children and many more. The purpose of this data collection was to establish the reasons of inclination of people towards these subscription-based models instead of other alternatives available. The survey was based on three major sectors of entertainment industry that is video streaming platforms, music streaming platforms and the subscription of news websites or apps. Data collection was done for 6 days in which the questionnaire form was circulated to the people from different demographics.

\subsection{Data Analysis}

After the process of data collection, the cleaning of data was done and it was captured in Microsoft Excel 2019 and then exported to SPSS version 25. In order to describe the socioeconomic characteristics of the consumers Descriptive Statistics (frequencies and percentages) was done. 


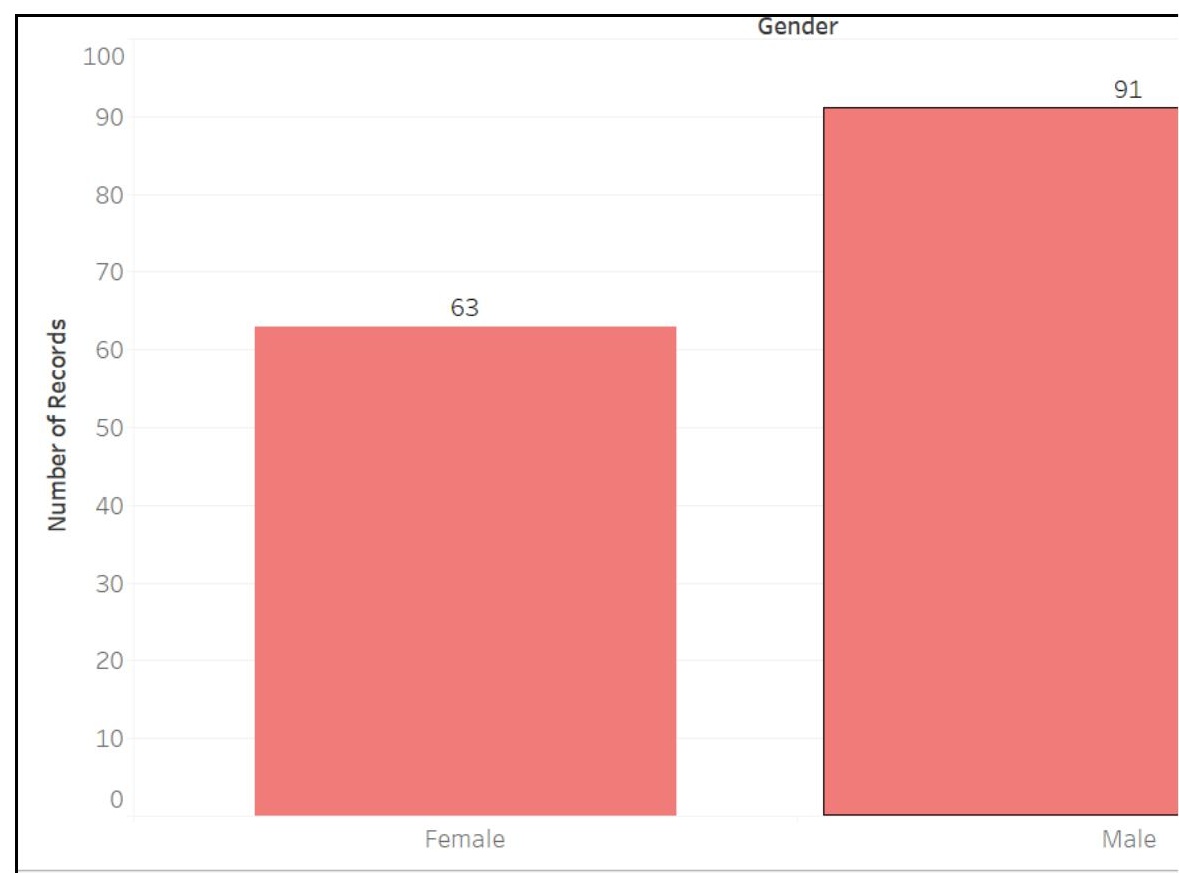

Fig 1: No of people in each category of gender

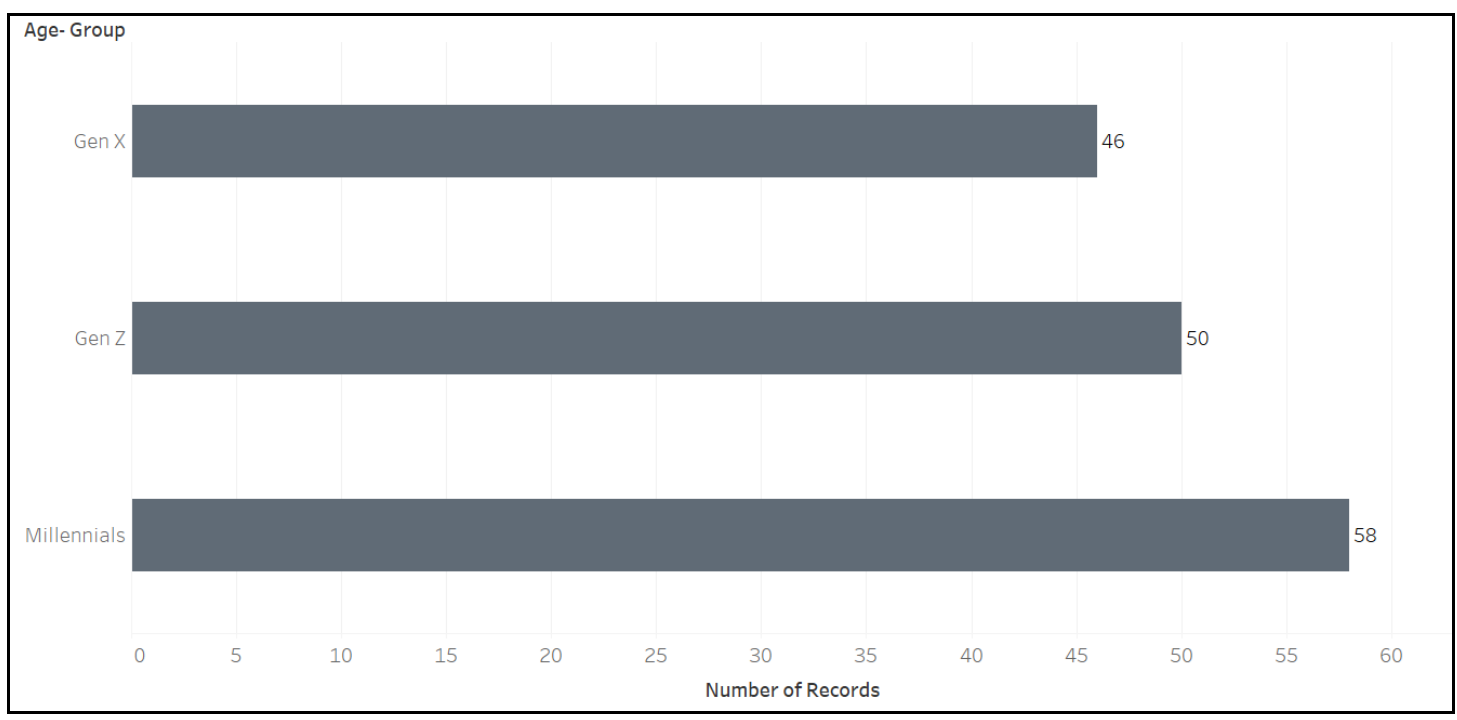

Fig 1: No of people in each category of age group 


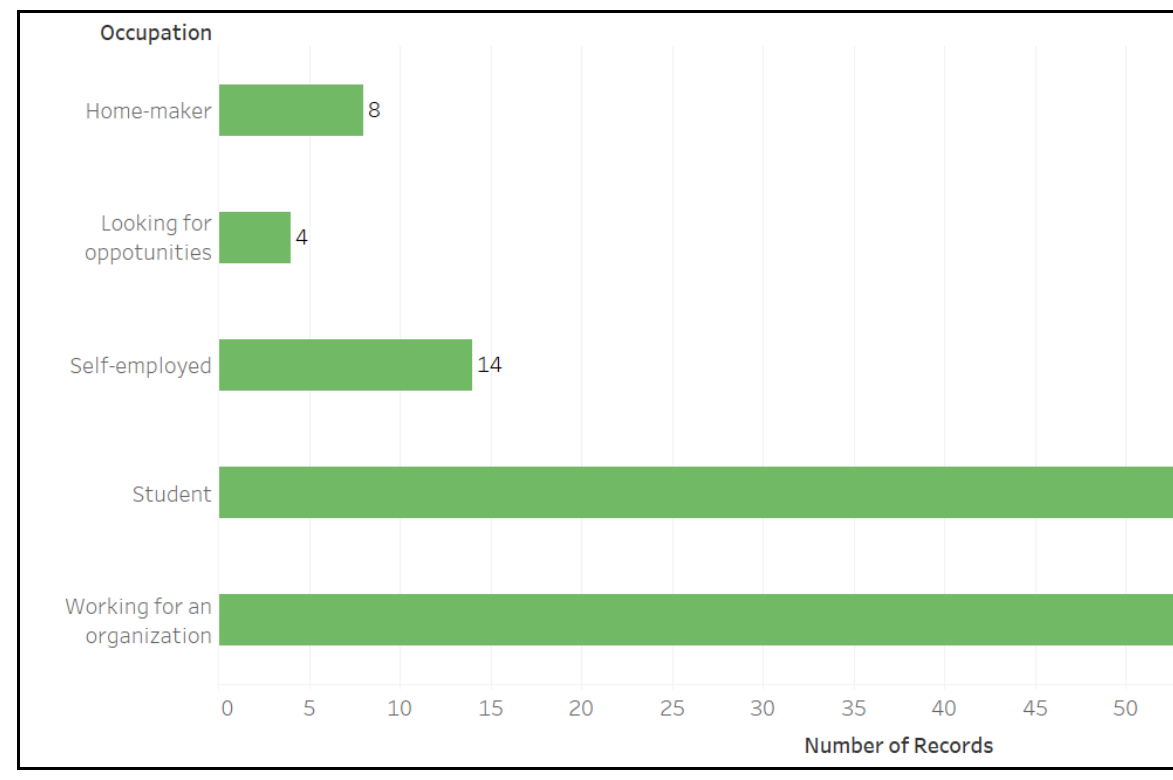

Fig 1: No of people in each Income group

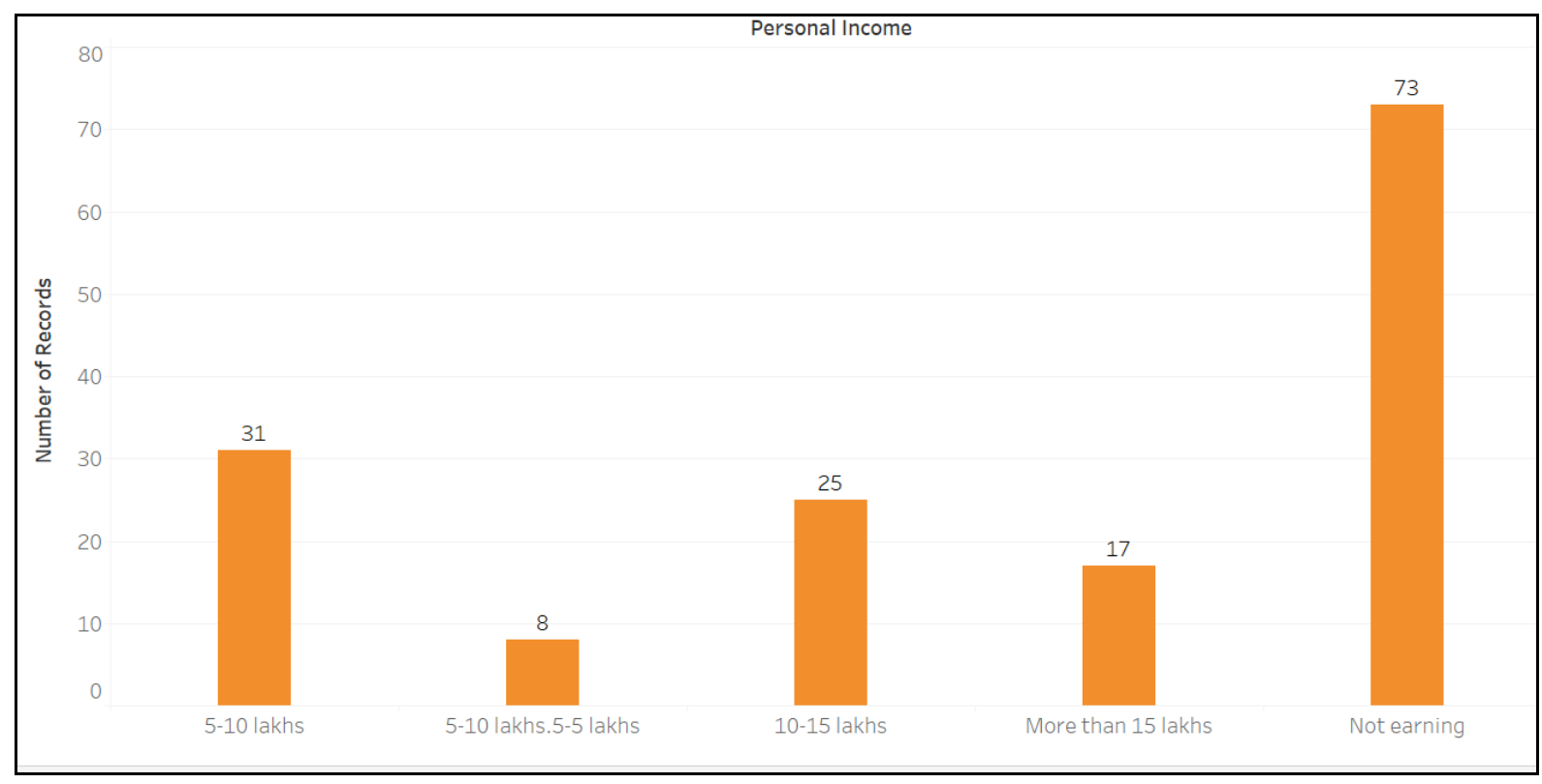

\section{Reliability Test}

Cronbach's alpha measures the internal consistency of data, which is the reliability.

\begin{tabular}{|l|l|l|}
\hline Cronbach's Alpha & $\begin{array}{l}\text { Cronbach's Alpha } \\
\text { Based on } \\
\text { standardized items }\end{array}$ & N of items \\
\hline .723 & .745 & 24 \\
\hline
\end{tabular}

\section{Table-1}

The Cronbach's Alpha came out to be 0.723 which is considered good and indicates a high level of internal consistency of the data.

This paper uses the methodology and application of the very popular non parametric test which is a rank-based test named as Kruskal-Wallis. This test can be used for comparing more than two independent sample. It tests whether such samples come from the same distribution. The statistical analysis of the given data for this paper was sone with the software SPSS.

The assumptions are less stringent when it comes to the nonparametric methods as compared to their parametric counterparts. These can be used when the assumptions of the parametric tests are not met.

The nonparametric equivalent of one-way ANOVA is Kruskal-Wallis test. This test is used to test whether the given samples originate from the same distribution. When the means of $k$ populations are compared, knowing that populations do not have equal variances or if they are not normal, the Kruskal-Wallis non parametric test is used [3,4]. No assumptions about normality are made in this test, However, it is assumed that the observations in each group is from population with the 


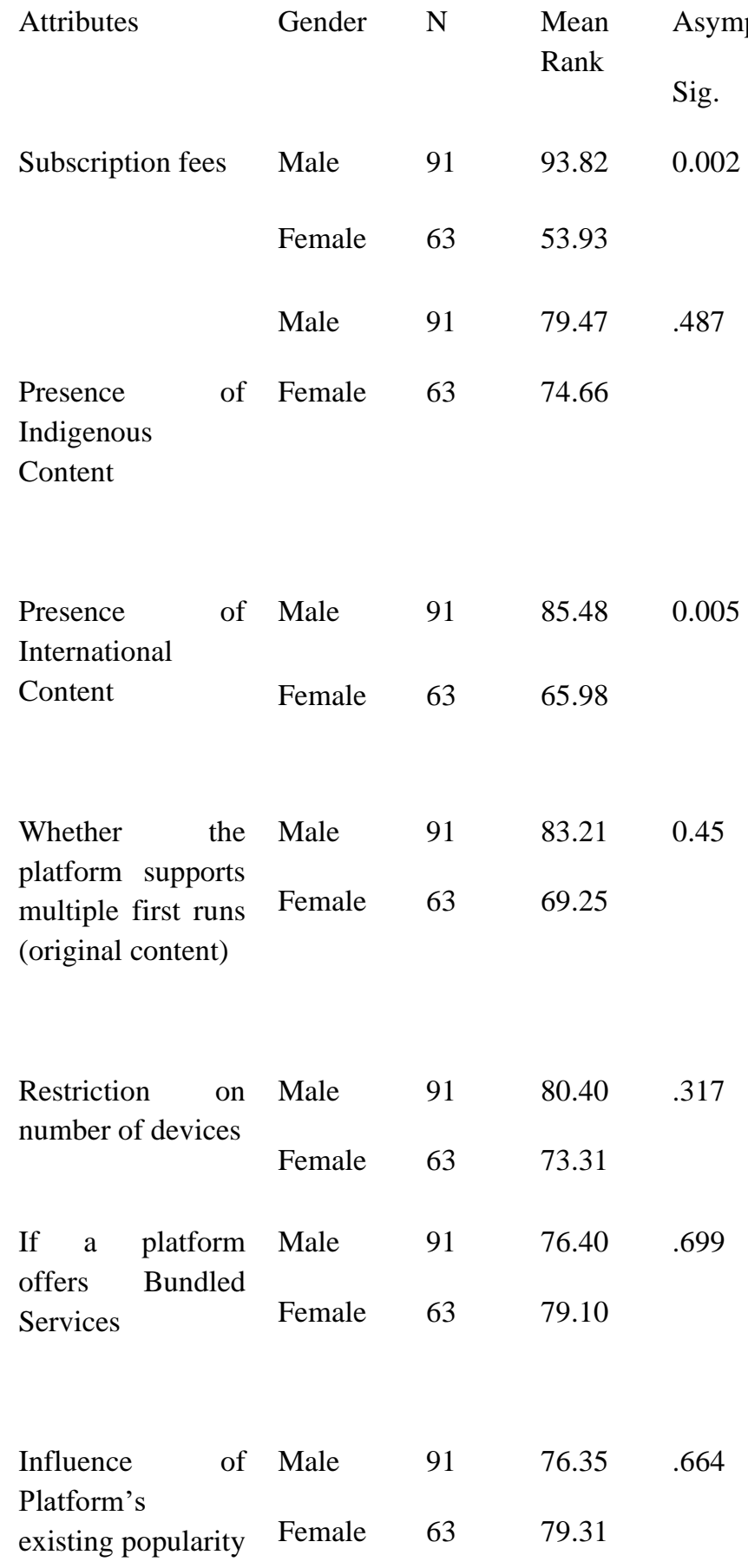

same shape of the distribution and the samples are independent and random.

The Media and Entertainment Industry was divided into three sectors, the Video streaming services, Music streaming services and the online newspapers. For each of these categories, different parameters were studied in order to understand the factors that drive the consumers to go for these services.

\section{VIDEO STREAMING SERVICES}

For video streaming services, various attributes that are provided by the today's subscription-based services offer over the traditional services were presented to the respondents and their preference for the same was judged.

For Gender,

Mann-Whitney test was used which is a non-parametric test like Kruskal but is applied when there are two categories of the testing variable

NULL HYPOTHESIS: There is no significant difference between gender groups of respondents towards the subscriptions of the video streaming services.

To examine the significant difference in the importance of different attributes among the gender group of respondents, Mann- Whitney U test was applied taking importance of attributes as Test field and Gender Group as Groups.

\section{Table-2}

The results in table 2, show that there are two attributes where the significance values are less than 0.05 i.e. the subscription fees and the presence of the international content which implies that there is a significant difference in genders while assessing the factors for subscription-based video-streaming services, and thus reject the hypothesis taken.

Looking at the mean scores for respective genders it can be seen that for males the subscription fee matters a lot more than females. This could be due to the fact that in India, males are still the breadwinner of the families and are thus more concerned about the spending.

Another factor that had a significant difference is the presence of International content. It has come to the notice that males are more inclined towards a video streaming service when International content is available as compares to the females.

Rest all factors, more or less mattered the same to both the genders and thus it can be concluded that there was no significant difference in the same.

\section{AGE-GROUP}

NULL HYPOTHESIS: There is no significant difference between age groups of respondents towards the subscriptions of the video streaming services.

To examine the significant difference in the importance of different attributes among the Age group of respondents, Kruskal- wallis test was applied taking importance of attributes as Test field and Age Group as Groups.

\begin{tabular}{|c|c|c|c|c|}
\hline \multirow[t]{2}{*}{ Attributes } & Gender & $\mathrm{N}$ & Mean & Asymp \\
\hline & & & Rank & Sig. \\
\hline \multirow[t]{3}{*}{ Subscription fees } & Gen Z & 50 & 68.87 & .216 \\
\hline & Millennial & 58 & 82.36 & \\
\hline & Gen X & 46 & 80.75 & \\
\hline \multirow{2}{*}{$\begin{array}{l}\text { Presence } \\
\text { Indigenous }\end{array}$} & Gen Z & 50 & 68.37 & .150 \\
\hline & Millennial & 58 & 84.03 & \\
\hline
\end{tabular}


Content

Gen X

46

79.20

$\begin{array}{lllll}\begin{array}{l}\text { Presence } \\ \text { International }\end{array} & \text { of } & \text { Gen Z } & 50 & 65.04 \\ \text { Content } & & \text { Millennial } & 58 & 85.83 \\ & & \text { Gen X } & 46 & 80.54\end{array}$

$\begin{array}{llcc}\begin{array}{l}\text { Whether the } \\ \text { platform supports }\end{array} & \text { Gen Z } & 50 & 79.48 \\ \begin{array}{l}\text { multiple first runs } \\ \text { (original content) }\end{array} & \text { Millennial } & 58 & 78.50 \\ & \text { Gen X } & 46 & 74.09\end{array}$

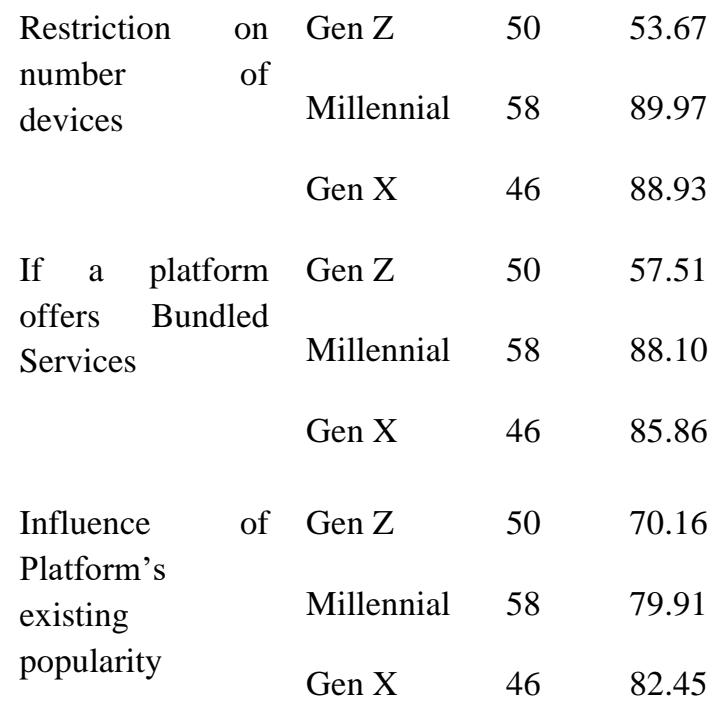

Table-3

The respondents were divided into three age groups namely Gen Z (14-23 years), Millennial (24-37 years) and Gen X (3854 years). From table 3, It can be seen that the attributes, Presence of International Content, Restriction on number of devices and the bundled services have a significance level of less than 0.05, implying that there is a significant difference in age-groups while assessing the factors for subscriptionbased video-streaming services, and thus reject the hypothesis taken.

From the above given mean score it can be seen that to Millennials the presence of International content is most important as compared to the other two age groups, attributed to the fact that there is an inclination of millennials to go global. Diversity of content is important to them and there is preference of International content over Indigenous content. Next talking about Restriction on number of devices is a deal maker for both Gen X and Millennials where they would like to have a choice of using a greater number of devices simultaneously

while subscribing to these services. Whereas, Gen $\mathrm{Z}$ is indifferent about this attribute and thus a low mean score. It doesn't make a much difference to them.

Amazon Prime offers a lot more than just the video streaming when subscribed. It includes music services, access to some books on kindle and also preference for delivery in the package. This is a driving factor for many people especially Millennial, where they seek value for money while going for services like these.

If you are a video streaming service, customers look out for bundled services which can be either a subscription to either music streaming or monthly books etc so as to get a feel that they are getting value for money by subscribing to your service. This is also contributed to the economic man approach theory as described earlier [8] where people tend to look for best deals in their options and not just core functions.

\section{PERSONAL INCOME}

NULL HYPOTHESIS: There is no significant difference between different income groups of respondents towards the subscriptions of the video streaming services.

To examine the significant difference in the importance of different attributes among the Income group of respondents, Kruskal- wallis test was applied taking importance of attributes as Test field and Income Group as Groups.

\begin{tabular}{|c|c|c|c|c|}
\hline Attributes & Gender & $\mathrm{N}$ & $\begin{array}{l}\text { Mean } \\
\text { Rank }\end{array}$ & $\begin{array}{l}\text { Asymp } \\
\text { Sig. }\end{array}$ \\
\hline \multirow[t]{5}{*}{ Subscription fees } & $\begin{array}{l}\text { Not } \\
\text { earning }\end{array}$ & 73 & 94.32 & .003 \\
\hline & $\begin{array}{l}2.5-5 \\
\text { lakhs }\end{array}$ & 8 & 84.94 & \\
\hline & 5-10 lakhs & 31 & 65.32 & \\
\hline & $\begin{array}{l}10-15 \\
\text { lakhs }\end{array}$ & 25 & 57.87 & \\
\hline & $\begin{array}{l}\text { More than } \\
15\end{array}$ & 17 & 52.34 & \\
\hline \multirow{4}{*}{$\begin{array}{l}\text { Presence } \\
\text { Indigenous } \\
\text { Content }\end{array}$} & $\begin{array}{l}\text { Not } \\
\text { earning }\end{array}$ & 73 & 70.94 & .103 \\
\hline & $\begin{array}{l}2.5-5 \\
\text { lakhs }\end{array}$ & 8 & 58.56 & \\
\hline & 5-10 lakhs & 31 & 89.76 & \\
\hline & $\begin{array}{l}10-15 \\
\text { lakhs }\end{array}$ & 25 & 78.42 & \\
\hline
\end{tabular}


More than $17 \quad 90.88$ 15

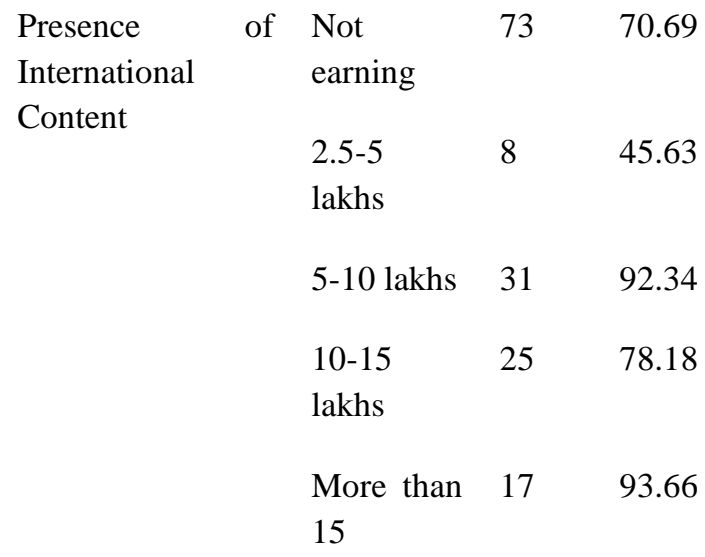

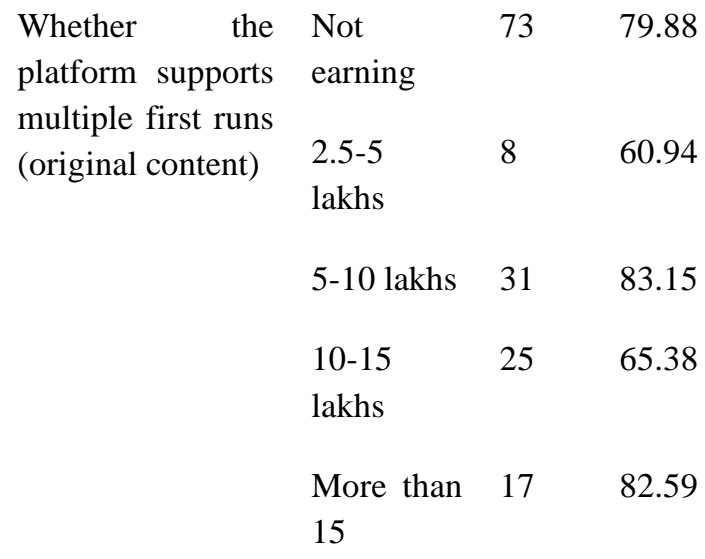

Restriction on number of devices

Not
earning

2.5-5

$\begin{array}{ll}73 & 75.87\end{array}$

.013

lakhs

5-10 lakhs $\quad 31 \quad 71.68$

10-15 $\quad 25 \quad 91.44$

lakhs

More than $17 \quad 80.62$

15

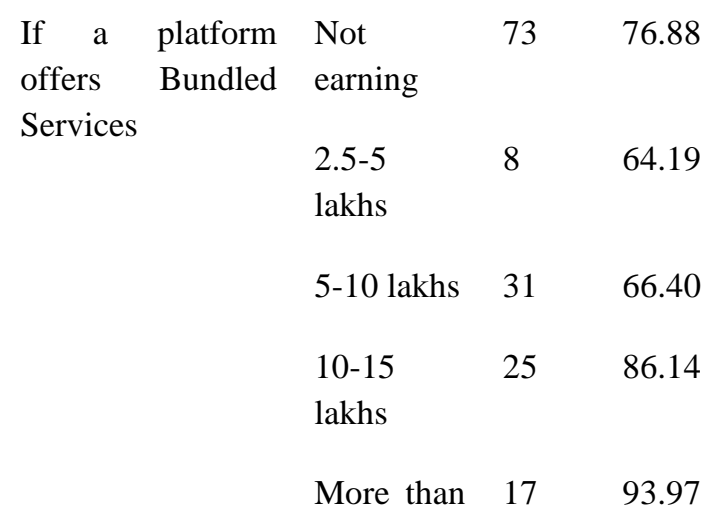

15

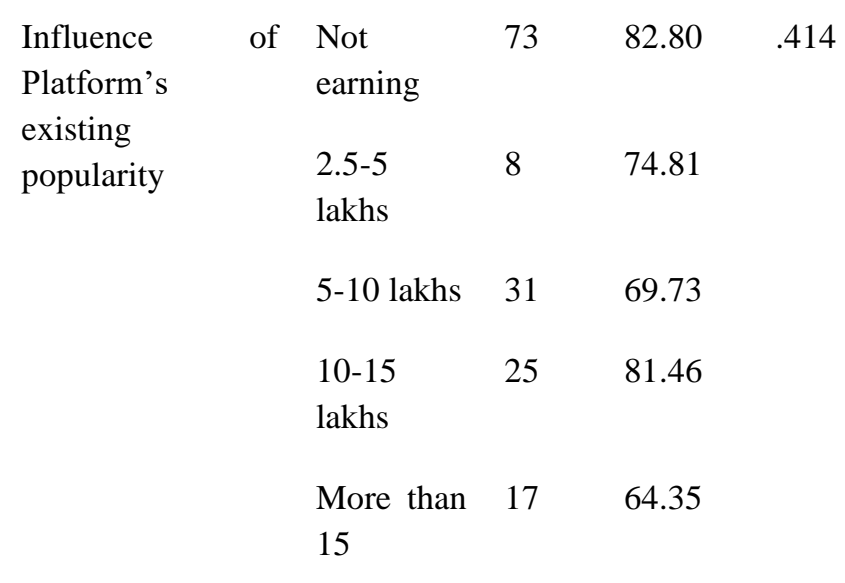

\section{Table-4}

The sample of respondents was divided into different categories of Income ranging from not earning to people earning more than 15 lakhs. These incomes were the incomes of the individuals from their respective professions and no consideration was given to the extra income. From table 3 it can be seen subscription fees and International content have a significance of less than 0.05 which implies there is a significant difference in people pf different income groups while assessing the factors for subscription-based videostreaming services, and thus reject the hypothesis taken.

It is to be noticed that Subscription fees as expected is a major concern for people from low income groups as compared to people from the high-income groups. It has also come to notice that people from high income groups are more concerned about the International content on the platform.

So, if a Video streaming service is planning to launch a platform with only Indigenous content then they can segment the market according to people's income and target the people from low income groups and positioning their product as the same.

\section{OCCUPATION}

NULL HYPOTHESIS: There is no significant difference between gender groups of respondents towards the subscriptions of the video streaming services.

To examine the significant difference in the importance of different attributes among the Occupation group of respondents, Kruskal- wallis test was applied taking importance of attributes as Test field and Occupation Group as Groups.

$\begin{array}{lllll}\text { Attributes } & \text { Gender } & \text { N } & \begin{array}{l}\text { Mean } \\ \text { Rank }\end{array} & \text { Asymp } \\ & & & & \text { Sig. } \\ & & 59 & 82.03 & 0.000\end{array}$


fees

$$
\text { Looking for } 4
$$

opportunities

Working for an 69

organization

$\begin{array}{lll}\text { Self-employed } & 14 & 101.39 \\ \text { Home-Maker } & 8 & 18.50\end{array}$

Presence
Indigenous

Content

of Stur

Student $\quad 59$

10.88

0.001

opportunities

Working for an $\quad 69 \quad 82.70$

organization

Self-employed $\quad 14 \quad 83.25$

Home-Maker $\quad 8 \quad 98.87$

Presence of Student $\quad 59 \quad 78.62$

International

Content

Looking for $4 \quad 56.50$

opportunities

Working for an 69

83.24

organization

Self-employed $\quad 14 \quad 89.36$

Home-Maker $\quad 8 \quad 32.51$

platform

supports

multiple first

runs (original

content)

Looking for $4 \quad 57.00$

opportunities

Working for an $69 \quad 69.80$ organization

Self-employed $\quad 14 \quad 99.93$

Home-Maker $\quad 8 \quad 18.75$

Restriction on Student $\quad 59 \quad 71.5$

.008

number of

devices

Looking for $4 \quad 62.75$

opportunities

Working for an $\quad 69 \quad 73.71$

organization

Self-employed $\quad 14 \quad 102.07$

Home-Maker $\quad 8 \quad 118.56$

\begin{tabular}{|c|c|c|c|}
\hline $\begin{array}{l}\text { If a platform } \\
\text { offers Bundled } \\
\text { Services }\end{array}$ & $\begin{array}{l}\text { Looking for } \\
\text { opportunities }\end{array}$ & 59 & 105.38 \\
\hline & $\begin{array}{l}\text { Working for an } \\
\text { organization }\end{array}$ & 69 & 71.26 \\
\hline & Self-employed & 14 & 100.36 \\
\hline & Home-Maker & 8 & 118.69 \\
\hline Influence of & Student & 59 & 80.36 \\
\hline $\begin{array}{l}\text { existing } \\
\text { popularity }\end{array}$ & $\begin{array}{l}\text { Looking for } \\
\text { opportunities }\end{array}$ & 4 & 67.00 \\
\hline & $\begin{array}{l}\text { Working for an } \\
\text { organization }\end{array}$ & 69 & 68.68 \\
\hline & Self-employed & 14 & 87.71 \\
\hline & Home-Maker & 8 & 119.81 \\
\hline
\end{tabular}

Table 5

The next category that was assessed was occupation. There were five categories for the same, namely Student, looking for opportunities, working for an organization, self-employed and Home-Maker.

Table 5 shows us that all attributes have a significance of less than 0.05 , thus all the attributes have a significant difference and thus reject the null hypothesis taken.

Next looking at the mean scores for each of the attribute. Subscription fee is most important for people who are selfemployed which can be attributed to the factor that the incomes are not regular and consistent. People who are working for an organization that is service class people have high regards for International content as compared to the house makers which don't seem to be much bothered by the International content.

One thing that is of utmost important to home makers is the platform's popularity. They seem to get influenced by the external factors rather than their own personal decisions. Also, importance is given to the bundled services from their end, which is highest as compared to all other categories. It has also come to the notice that homemakers prefer indigenous content over international content.

MUSIC STREAMING

Music streaming Industry is growing in India. With international content on their hands with minimal fee, more people are getting inclined towards

\section{GENDER}

NULL HYPOTHESIS: There is no significant difference between gender groups of respondents towards the subscriptions of the music streaming services. 
To

examine the significant difference in the importance of different attributes among the Gender group of respondents, Mann-Whitney $U$ test was applied taking importance of attributes as Test field and Gender Group as Groups.

\begin{tabular}{|c|c|c|c|}
\hline Attributes & Gender & $\mathrm{N}$ & $\begin{array}{l}\text { Mean } \\
\text { Rank }\end{array}$ \\
\hline
\end{tabular}

$\begin{array}{llll}\text { Subscription fees } & \text { Male } & 91 & 80.61 \\ & \text { Female } & 63 & 73.01\end{array}$

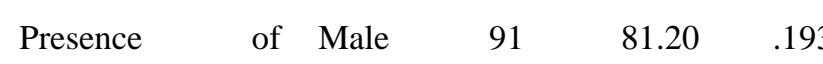

Indigenous Music

\begin{tabular}{|c|c|c|c|c|}
\hline - & Female & 63 & 72.16 & \\
\hline $\begin{array}{l}\text { Presence of } \\
\text { International }\end{array}$ & Male & 91 & 75.96 & .586 \\
\hline Music & Female & 63 & 79.72 & \\
\hline \multirow[t]{2}{*}{ Regular Podcast } & Male & 91 & 72.08 & 0.062 \\
\hline & Female & 63 & 85.33 & \\
\hline \multirow{3}{*}{$\begin{array}{l}\text { Playlist curated } \\
\text { with Artificial } \\
\text { Intelligence }\end{array}$} & Male & 91 & 81.70 & .144 \\
\hline & Female & 63 & 71.43 & \\
\hline & Male & 91 & 74.45 & .335 \\
\hline Popularity & Female & 63 & 81.48 & \\
\hline
\end{tabular}

\section{Table 6}

In table 6 , it can be seen that all the significance values are greater than 0.05 which implies there is no significant difference between the gender groups of respondents. Hence, the null hypothesis taken into consideration is accepted.

The result shows that all the attributes matter almost equally if the market is segmented on the basis of gender.

\section{AGE-GROUP}

NULL HYPOTHESIS: There is no significant difference between age groups of respondents towards the subscriptions of the music streaming services.

To examine the significant difference in the importance of different attributes among the Age group of respondents, Kruskal- wallis test was applied taking importance of attributes as Test field and Age Group as Groups.

\begin{tabular}{|c|c|c|c|c|}
\hline Attributes & Gender & $\mathrm{N}$ & $\begin{array}{l}\text { Mean } \\
\text { Rank }\end{array}$ & $\begin{array}{l}\text { Asymp } \\
\text { Sig. }\end{array}$ \\
\hline \multirow[t]{3}{*}{ Subscription fees } & Gen Z & 50 & 77.88 & .573 \\
\hline & Millennial & 58 & 81.22 & \\
\hline & Gen X & 46 & 72.39 & \\
\hline \multirow{3}{*}{$\begin{array}{l}\text { Presence } \\
\text { Indigenous } \\
\text { Music }\end{array}$} & Gen Z & 50 & 77.38 & .503 \\
\hline & Millennial & 58 & 81.89 & \\
\hline & Gen X & 46 & 72.10 & \\
\hline \multirow{3}{*}{$\begin{array}{l}\text { Presence } \\
\text { International } \\
\text { Music }\end{array}$} & Gen Z & 50 & 94.32 & 0.049 \\
\hline & Millennial & 58 & 83.77 & \\
\hline & Gen X & 46 & 59.34 & \\
\hline \multirow[t]{3}{*}{ Regular Podcast } & Gen Z & 50 & 74.00 & .669 \\
\hline & Millennial & 58 & 81.32 & \\
\hline & Gen X & 46 & 76.49 & \\
\hline \multirow{3}{*}{$\begin{array}{l}\text { Playlist curated } \\
\text { with Artificial } \\
\text { Intelligence }\end{array}$} & Gen Z & 50 & 73.48 & .671 \\
\hline & Millennial & 58 & 80.88 & \\
\hline & Gen X & 46 & 77.61 & \\
\hline \multirow[t]{3}{*}{ Popularity } & Gen Z & 50 & 79.42 & .924 \\
\hline & Millennial & 58 & 76.25 & \\
\hline & Gen X & 46 & 76.99 & \\
\hline
\end{tabular}

Table 7

In table 7, it can be seen that the significance of the attribute 'Presence of International music' is less than 0.05 which implies there is a significant difference in between the age groups while looking for the subscription-based services and hence the null hypothesis taken into consideration is rejected. It can be seen from the mean scores that the presence of international music matters the most to the Gen $\mathrm{Z}$ and least to the Gen $X$. The new generation is inclined towards the global content and thus have high priority of International content as compared to other age groups.

\section{PERSONAL INCOME}

NULL HYPOTHESIS: There is no significant difference between Income groups of respondents towards the subscriptions of the music streaming services.

To examine the significant difference in the importance of different attributes 
amon

$\mathrm{g}$ the Income group of respondents, Kruskal- wallis test was applied taking importance of attributes as Test field and Income Group as Groups.

\begin{tabular}{|c|c|c|c|c|}
\hline \multirow[t]{2}{*}{ Attributes } & \multirow[t]{2}{*}{ Gender } & \multirow[t]{2}{*}{$\mathrm{N}$} & \multirow{2}{*}{$\begin{array}{l}\text { Mean } \\
\text { Rank }\end{array}$} & Asymp \\
\hline & & & & Sig. \\
\hline \multirow[t]{7}{*}{ Subscription fees } & $\begin{array}{l}\text { Not } \\
\text { earning }\end{array}$ & 73 & 77.48 & .612 \\
\hline & $2.5-5$ & 8 & 69.88 & \\
\hline & lakhs & & & \\
\hline & 5-10 lakhs & 31 & 78.31 & \\
\hline & $10-15$ & 25 & 86.00 & \\
\hline & lakhs & & & \\
\hline & $\begin{array}{l}\text { More than } \\
15\end{array}$ & 17 & 71.91 & \\
\hline \multirow{8}{*}{$\begin{array}{l}\text { Presence of } \\
\text { Indigenous Music }\end{array}$} & Not & 73 & 77.16 & .048 \\
\hline & earning & & & \\
\hline & $2.5-5$ & 8 & 47.94 & \\
\hline & lakhs & & & \\
\hline & 5-10 lakhs & 31 & 68.66 & \\
\hline & $10-15$ & 25 & 86.43 & \\
\hline & lakhs & & & \\
\hline & $\begin{array}{l}\text { More than } \\
15\end{array}$ & 17 & 95.85 & \\
\hline \multirow{6}{*}{$\begin{array}{l}\text { Presence } \\
\text { International } \\
\text { Music }\end{array}$} & $\begin{array}{l}\text { Not } \\
\text { earning }\end{array}$ & 73 & 78.42 & 0.002 \\
\hline & $\begin{array}{l}2.5-5 \\
\text { lakhs }\end{array}$ & 8 & 40.69 & \\
\hline & 5-10 lakhs & 31 & 64.50 & \\
\hline & $10-15$ & 25 & 83.64 & \\
\hline & lakhs & & & \\
\hline & $\begin{array}{l}\text { More than } \\
15\end{array}$ & 17 & 105.56 & \\
\hline \multirow[t]{2}{*}{ Regular Podcast } & $\begin{array}{l}\text { Not } \\
\text { earning }\end{array}$ & 73 & 78.97 & .180 \\
\hline & $\begin{array}{l}2.5-5 \\
\text { lakhs }\end{array}$ & 8 & 56.00 & \\
\hline
\end{tabular}

$\begin{array}{lll}\begin{array}{l}\text { 5-10 lakhs } \\ \text { 10-15 }\end{array} & 31 & 68.52 \\ \text { lakhs } & 25 & 92.12\end{array}$

More than $17 \quad 76.21$

15

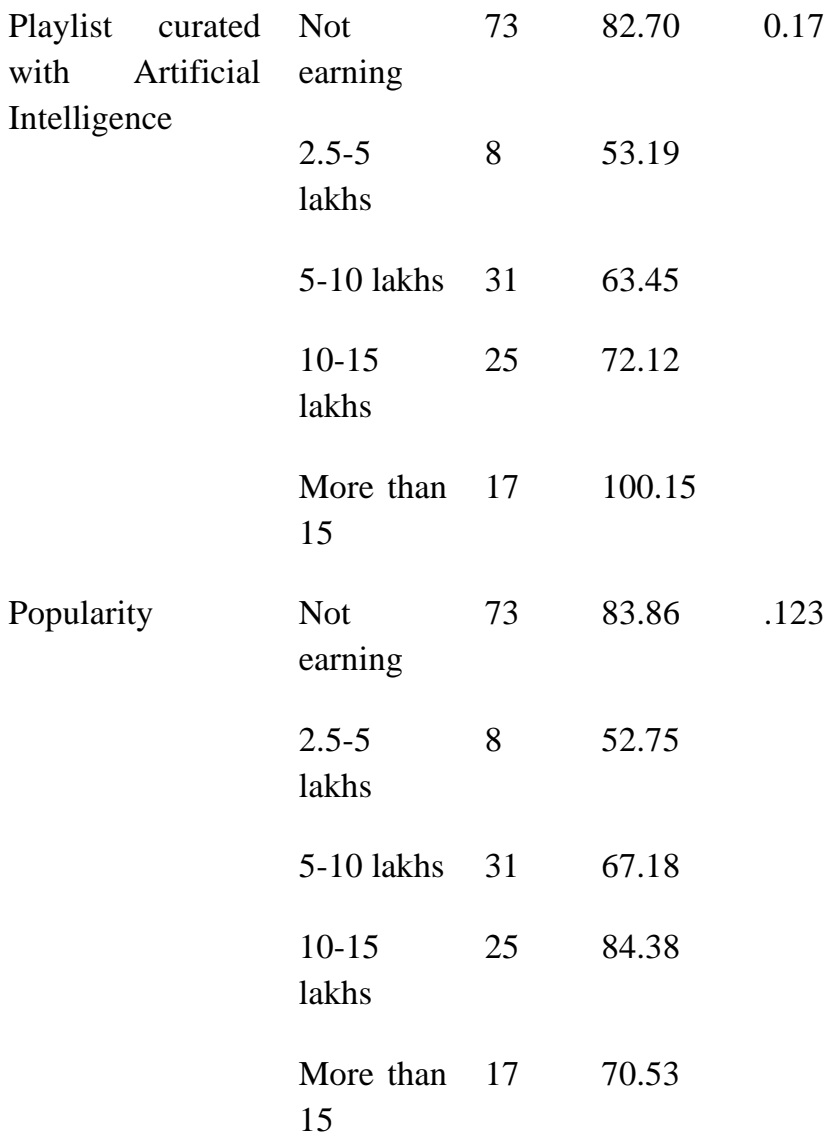

Table-8

In the table 8 , given above, two of the attributes 'Presence of Indigenous content' and 'Presence of International content has a significance of lower than 0.05 which implies that there is a significant difference between the incomes groups of respondents and thus the null hypothesis taken into consideration is rejected.

From the mean scores of these attributes, it was observed that people in salary group of over 15 LPA have content as a priority while selecting a music streaming service. They expect to have variety of both indigenous music and international music and matters to them the most.

Apart from this it can also be seen that automated playlist are also important for people falling in income group of over 15LPA. Automatically curated playlist is another important factor for people in this income group. Nowadays, most of the streaming services come with automated playlist option which is curated based on the preferences or music choices of the user. In the times of digitisation, personalization is the best way to engage your consumer. 
NUL

L HYPOTHESIS: There is no significant difference between occupation groups of respondents towards the subscriptions of the music streaming services.

To examine the significant difference in the importance of different attributes among the Occupation group of respondents, Kruskal- wallis test was applied taking importance of attributes as Test field and Occupation Group as Groups.

\begin{tabular}{|c|c|c|c|c|}
\hline Attributes & Gender & $\mathrm{N}$ & $\begin{array}{l}\text { Mean } \\
\text { Rank }\end{array}$ & $\begin{array}{l}\text { Asymp } \\
\text { Sig. }\end{array}$ \\
\hline \multirow{5}{*}{$\begin{array}{l}\text { Subscription } \\
\text { fees }\end{array}$} & Student & 59 & 84.25 & .001 \\
\hline & $\begin{array}{l}\text { Looking for } \\
\text { opportunities }\end{array}$ & 4 & 102.13 & \\
\hline & $\begin{array}{l}\text { Working for an } \\
\text { organization }\end{array}$ & 69 & 73.75 & \\
\hline & Self-employed & 14 & 92.68 & \\
\hline & Home-Maker & 8 & 21.19 & \\
\hline \multirow{5}{*}{$\begin{array}{l}\text { Presence } \\
\text { Indigenous } \\
\text { Music }\end{array}$} & Student & 59 & 81.39 & .021 \\
\hline & $\begin{array}{l}\text { Looking for } \\
\text { opportunities }\end{array}$ & 4 & 77.75 & \\
\hline & $\begin{array}{l}\text { Working for an } \\
\text { organization }\end{array}$ & 69 & 74.86 & \\
\hline & Self-employed & 14 & 97.68 & \\
\hline & Home-Maker & 8 & 36.19 & \\
\hline \multirow{5}{*}{$\begin{array}{l}\text { Presence of } \\
\text { International } \\
\text { Music }\end{array}$} & Student & 59 & 113.56 & .109 \\
\hline & $\begin{array}{l}\text { Looking for } \\
\text { opportunities }\end{array}$ & 4 & 79.25 & \\
\hline & $\begin{array}{l}\text { Working for an } \\
\text { organization }\end{array}$ & 69 & 75.49 & \\
\hline & Self-employed & 14 & 87.14 & \\
\hline & Home-Maker & 8 & 72.55 & \\
\hline \multirow{3}{*}{$\begin{array}{l}\text { Regular } \\
\text { Podcast }\end{array}$} & Student & 59 & 81.16 & .574 \\
\hline & $\begin{array}{l}\text { Looking for } \\
\text { opportunities }\end{array}$ & 4 & 92.63 & \\
\hline & $\begin{array}{l}\text { Working for an } \\
\text { organization }\end{array}$ & 69 & 73.98 & \\
\hline
\end{tabular}

\begin{tabular}{|c|c|c|c|c|}
\hline & Self-employed & 14 & 84.54 & \\
\hline & Home-Maker & 8 & 61.00 & \\
\hline \multirow{5}{*}{$\begin{array}{l}\text { Playlist curated } \\
\text { with Artificial } \\
\text { Intelligence }\end{array}$} & Student & 59 & 82.02 & .022 \\
\hline & $\begin{array}{l}\text { Looking for } \\
\text { opportunities }\end{array}$ & 4 & 108.75 & \\
\hline & $\begin{array}{l}\text { Working for an } \\
\text { organization }\end{array}$ & 69 & 66.92 & \\
\hline & Self-employed & 14 & 101.79 & \\
\hline & Home-Maker & 8 & 77.31 & \\
\hline \multirow[t]{5}{*}{ Popularity } & Student & 59 & 84.83 & .051 \\
\hline & $\begin{array}{l}\text { Looking for } \\
\text { opportunities }\end{array}$ & 4 & 66.54 & \\
\hline & $\begin{array}{l}\text { Working for an } \\
\text { organization }\end{array}$ & 69 & 100.75 & \\
\hline & Self-employed & 14 & 85.61 & \\
\hline & Home-Maker & 8 & 97.38 & \\
\hline
\end{tabular}

\section{Table 9}

In table 9, It can be seen that the attributes like subscription fees, presence of indigenous content and automatically curated playlist have significance lower than 0.05 which implies that there is a significant difference between the different occupation groups of respondents and thus the null hypothesis taken is rejected.

Looking at the mean scores it can be inferred that people looking for new opportunities and are not currently working give more importance to the subscription fees that these streaming services take. These people tend to get more inclined towards streaming services that charge lower.

Also, presence of Indigenous content and automated playlists are factors that matters significantly for people who are selfemployed and looking for opportunities which implies that content matters to them when subscribing to services like these.

\section{ONLINE NEWSPAPERS}

The online newspapers in India are still in nascent stage. People do download the apps to usually have access to the content that is free. People are still sceptical about paying the fee for subscriptions fees for these services. In the study conducted for one fifty-four people the following were the responses 


\section{Do you read online newspapers/magazines?}

Fig 3: no of people who read online newspapers

Out of the survey for 154 people 122 respondents said that they do read online newspapers on primary bases, although the results for the subscription aspect of it was something to notice. The following graph shows the number of people who have actually subscribed to these platforms.

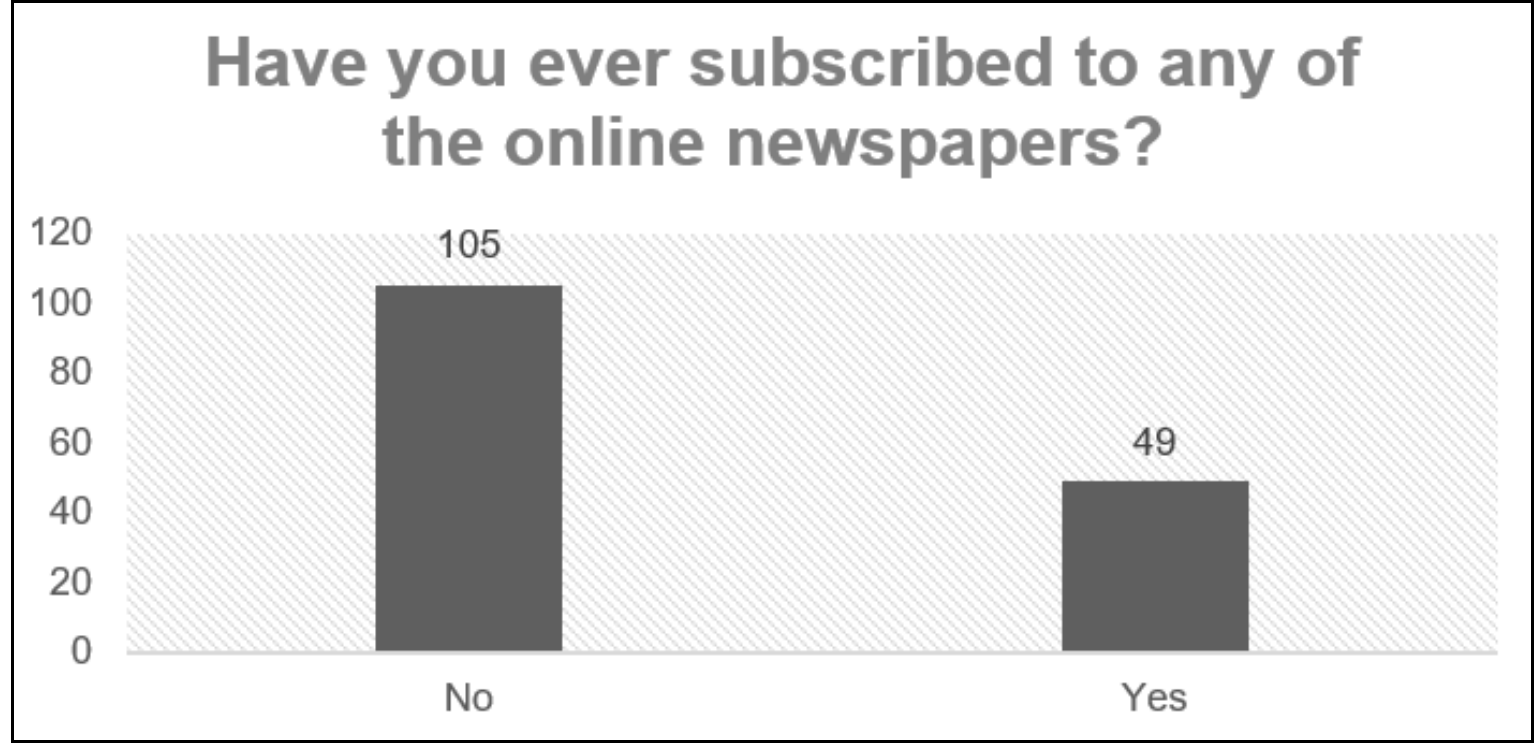

Fig 4: no of people who have subscribed to online newspapers

Over here it can be seen that 105 respondents said no to having subscribed to online newspapers. The findings include people from all the demographics. The findings show that although people are inclined towards reading online newspapers, subscription fees is something they are not really sure about. For such platforms an -advertisement based business model can be more useful as compared to subscription-based models. People were okay with seeing the advertisements along with the content instead of paying for subscriptions.

Respondents were asked about the attributes that make them go for online newspapers or sources of news like apps etc. The results are from various demographics as people were given multiple options to select their reasons. The findings showed that 51.9 percent of the people said that they opt for online newspapers out of personal Interest while whereas 68.18 percent of respondents said that it is because of their lifestyle and thus as a faster and easily accessible resource they look for this alternative. 44.15 percent of the respondents also said that it is because of the quality of the content on these platforms that drive their decision. It can be seen that people are looking for good content and a one stop solution for all the type of news. They look for variety of content at one place be it finance or economy related news or news related to the entertainment industry.

The online news industry in India is still in nascent stage and the customer base is increasing day by day. People are reluctant to pay for this service and currently okay with not having access to the premium content. An ad-based business model is more suitable for the upcoming businesses in this domain and later on they can try for the freemium model as well. Content is 
somet

hing these businesses can and should focus on, providing their reader one platform for everything.

\section{LIMITATIONS}

The study has been completed in limited time, so a time factor consideration might not justify the actual study.

Convenience sampling was done in order to conduct the study and it might not be able to give proper justification.

The sample size taken was very limited and thus the findings may or may not align with the that of larger population.

\section{IMPLICATIONS}

The purpose of the paper is to identify and assess the factors that influence a customer's decision to go for subscriptionbased entertainment services. The demand for these subscription-based services has been on rise in India. In India, there are many new platforms coming up with subscriptionbased services which are now becoming increasingly popular amongst the people. This increase in competition has resulted in these services becoming more consumer-centric. They are trying to give their consumers a more personalized experience to retain them for as long as possible. It therefore becomes essential for them to understand their customer better in order to make better offerings. This paper helps these companies to understand the demands of their customers well, segment the customer base, target accordingly and then position it after analysing it. The subscription model of pricing is becoming popular in not only entertainment industry but also in other businesses as well. This paper can help understand them the consumer's attitude towards the subscription model of pricing

1. The results show that it is important to recognize how demographic characteristics such as age, gender, occupation of the consumers has a significant influence on the subscribing decision of the customer. The service providers can formulate strategies and then target their customers based on these readings. Personalization has been one of the crucial factors in defining the strategies of these subscription services. Marketers can look for these insights and thus plan their promotional tactics.

2. The demographic factors help with the positioning of the service. Understanding the customer's perspective towards these services can help them serve better and also realise the gap in the promotional strategy which can further help in engaging the customers.

3. The findings indicate that not just subscription fees but also other factors like presence of both indigenous and international content plays a crucial role in consumer's decision to go for these services.

4. For music streaming services it could be seen that the platforms that provide automatically curated playlist are more popular in many demographics of people. Music platforms like spotify and saavn can look for these findings and accordingly can create a

platform to provide their customer with playlist curated according to their moods.

5. Not many papers are available which judge the specific attributes involved in the decision-making process of the consumers. This paper can help marketers understand what is sold where and thus do a better positioning of their services. CONCLUSION

In this paper it has been found the different attributes essential for different demographics that effect consumer's behaviour while making decision for subscribing to online entertainment services. In this paper majorly three services video streaming, music streaming and online newspapers have been taken into consideration to understand the decision-making process of the customers.

With the advent of Internet and the penetration of Internet rising in Indian markets people are switching to the online platforms as major sources of entertainment. With these concepts coming into picture, businesses and marketers are looking for different business models. In order to make subscription-based models successful it becomes essential for marketers to engage their customers regularly. With this in mind they can look at the attributes given above in order to segments the market better, target the correct customer base and position the value sought by the targeted customers.

The results show us that various attributes matter to different demographics be it for video streaming services or music streaming. People have varied preferences while making a decision to subscribe for these services.

Online newspapers are in their nascent stage in India currently. Results show people are currently still sceptical about subscribing to these services. Hence recommended aan adbased business model for the same

This paper brings insights to marketing department of these service providers to come up with innovative solutions and thus can grow their businesses.

\section{REFERENCES}

[1]. 1. Du Plooy, G.M. Techniques, methods and applications. In Communication Research, 2nd ed.; Juta and Company Ltd.: Lansdowne, South Africa, 2009.

[2]. 2. Pawlowsky-Glahn, V.; Buccianti, A. Compositional Data Analysis: Theory and Applications; John Wiley \& Sons, Ltd.: West Sussex, UK, 2011; p. 214.

[3]. 3. D.C. Montgomery, G.C. Runger, Applied Statistics and Probability for Engineers, John Wiley \& Sons, New York, 2003.

[4]. 4. E. Ostertagová, O. Ostertag, Methodology and Application of One-way ANOVA, in: American Journal of Mechanical Engineering, 2013, Vol. 1, No. 7, pp. 256-261.

[5]. 5. Lee, H.J.; Yun, Z.S. Consumers' perceptions of organic 
ood attributes and cognitive and affective attitudes as determinants of their purchase intentions toward organic food. Food Qual. Prefer. 2015, 39, 259-267

[6]. 6. Anand, V. Effectiveness of Constructivist Approach in Teaching Learning History in Terms of Achievement. Int. Educ. Res. J. 2017, 3, 293 295. 34.

[7]. 7. Biddulph, F.; Carr, K. Learning theories and curriculum. Teach. Curric. 1999, 3, 31-35. [CrossRef]

[8]. 8. Becker, G.S. The Economic Approach to Human Behaviour; University of Chicago Press: Chicago, IL, USA, 2013.

[9]. 9. Oseyomon, P.E.; Ibadin, L.A. Perceived customer patronage of transport companies in a developing country. Int. J. Bus. Financ. Manag. Res. 2016, 4, 102-108.

[10]. 10. Mühlbach, S., \& Arora, P. (2020). Behind the music: How labor changed for musicians through the subscription economy. First Monday, 25(4).

[11]. 11. Suryakala, B. (2019). Towards A Subscription Economy: Digital Transformation Journey of a Traditional Product-Based Company (Master's thesis).

[12]. 12. Tzuo, T., \& Weisert, G. (2018). Subscribed: Why the Subscription Model Will be Your Company's Future-and what to Do about it. Penguin

[13]. 13. Huang, T. Y., Handigol, N., Heller, B., McKeown, N., \& Johari, R. (2012, November). Confused, timid, and unstable: picking a video streaming rate is hard. In Proceedings of the 2012 internet measurement conference (pp. 225-238).

[14]. 14. Fitzgerald, S. (2019). Over-the-Top Video Services in India: Media Imperialism after Globalization. Media Industries Journal, 6(1), 0000 .

[15]. 15. Mehta, S., \& Kaye, D. B. V. (2019). Pushing the next level: Investigating digital content creation in India. Television \& New Media, 1527476419861698.

[16]. 16. Moochhala, Q. (2018). The Future of Online OTT Entertainment Services in India.

[17]. 17. Sivamol, S., \& Suresh, K. (2019). Personalization Phenom: User-centric Perspectives towards Recommendation Systems in Indian Video Services. SCMS Journal of Indian Management, 16(2), 73-86.

[18]. 18. Pandit, M., \& Parmar, K. (2020). Evolution of Mediated Youth Culture: OTT as 'New Television'in India. In Off and Online Journalism and Corruption-International Comparative Analysis. IntechOpen. f [19]. 19 .

Sundaravel, E., \& Elangovan, N (2020). Emergence and future of Over-the-top (OTT) video services in India: an analytical research.

[20]. 20. Gaoshinde, M. (2020). Impact of embedded marketing on OTT Platforms.

[21]. 21. Chatterjee, M., \& Pal, S. (2020). Globalization propelled technology often ends up in its microlocalization: Cinema viewing in the time of OTT. Global Media Journal: Indian Edition, 12(1).

[22]. 22.Mehta, S. (2019). Precarity and new media: through the lens of indian creators. International Journal of Communication, 13, 5548-5567.

[23]. 23. Dasgupta, D., \& Grover, D. (2019). Understanding Adoption Factors of Over-the-Top Video Services Among Millennial Consumers. International Journal of Computer Engineering and Technology, 10(1).

[24]. 24. Tewari, P. (2015). The habits of online newspaper readers in India. Intermedia International E-journal, 2(2).

[25]. 25. Boczkowski, P. (1999). Understanding the development of online newspapers: Using computer-mediated communication theorizing to study Internet publishing. New Media \& Society, 1(1), 101-126.

[26]. 26. Prey, R. (2020). Locating power in platformization: Music streaming playlists and curatorial power. Social Media+ Society, 6(2), 2056305120933291.

[27]. 27. Selvakumar, E., Huang, J., Aidi, L., Markendahl, J. I., Tollmar, K., \& Blennerud, G (2012). How can Mobile Music Streaming Service Take off in India, China and Indonesia.

[28]. 28. Mehra, A. Indie indian music--market trends in indie music production and dissemination in india.

[29]. 29. Madahi, A.; Sukati, I. The effect of external factors on purchase intention amongst young generation in Malaysia. Int. Bus. Res. 2012, 5, 153. 